\title{
The Application of Graded Teaching Pattern in College English Classroom Teaching
}

\author{
Jiqun Ding \\ School of Culture and Arts, Zhejiang Technical Institute of Economics, Hangzhou, China \\ Email: tingjq69@163.com
}

How to cite this paper: Ding, J. Q. (2017). The Application of Graded Teaching Pattern in College English Classroom Teaching. Creative Education, 8, 272-278. https://doi.org/10.4236/ce.2017.82021

Received: January 10, 2017

Accepted: February 25, 2017

Published: February 28, 2017

Copyright $\odot 2017$ by author and Scientific Research Publishing Inc. This work is licensed under the Creative Commons Attribution International License (CC BY 4.0).

http://creativecommons.org/licenses/by/4.0/

\begin{abstract}
The graded teaching pattern, which takes different and targeted teaching methods according to students' English foundation and their distincted enthusiasm in English learning, is becoming one of the most common methods of teaching in College English teaching. This paper analyzes briefly the practices and explorations of graded teaching pattern in college English teaching in China in recent years, clears up relevant theoretical basis, and discusses the problems and deficiencies of this patter in application.
\end{abstract}

\section{Keywords}

Graded Teaching Pattern, College English, Classroom Teaching

\section{Introduction}

Because of the university enrollment expansion, there have been great changes in the number of students compared to decade years ago. As to many colleges and universities, especially the not key colleges and universities, there is obvious gap between the new enrolled students' academic levels. Even for the students of the same class, it is hard to achieve unity in learning progress.

Nowadays, Ministry of Education in China encourages quality-oriented education. The traditional teaching method which considers all the students the same is unable to meet the needs of the current education requirement. Students with relatively good English basis will feel easy and lose enthusiasm as a result while students with poor English foundation will feel too difficult and lose confidence of learning. To deal with this situation, graded teaching pattern comes into being (Dai, 2015). The graded teaching pattern originated from America. But now many universities and colleges are trying to adopt this teaching me- 
thod.

\section{The Theory Basis of Graded Teaching Pattern in College English Teaching}

The concept of graded teaching pattern in college English teaching is to adopt different teaching methods according to different knowledge and different abilities of students, based on the class teaching system and targeted at the teaching goals and teaching requirements of college English. The different abilities of students is about the difference in the cognitive level and personality. When teachers adopts this teaching method, they will need to consider the students' adaptive abilities in learning and their different basises, and then choose the suitable teaching methods. The main purpose is to improve the quality of college English teaching, and the essence is teaching strategy.

The ancient Chinese educationalist Confucius put forward "teach students in accordance with their aptitude". The essence of this theory is the graded teaching progress in graded teaching pattern. The truth of this teaching idea is to admit the existence of difference, and then teach distinguishingly. The American educationist Bloom once proposed the theory of mastery learning, in which he advocated that teachers just need to provide appropriate assistance when students are learning fixed materials. In this case, most of the students can complete the study task and achieve good learning effects. He believes that teachers should make different learning goals for different students, and then determine their teaching strategies combined with the goals. Teaching goals should be determined on the basis of students' learning level, learning ways and their characters. When carrying out teaching tasks, teachers should consciously make corresponding teaching strategies and provide for students a comprehensive learning experience which includes mass instruction, group study and individual study. Besides, daily teaching effect should be assessed as standard of teachers' evaluation. The former Soviet union educator Vogotsgy presents the "zone of proximal development (ZPD)" which also advocates that students have two different levels of development-one is the current level and the other is potential level. The section between the two levels is called the "zone of proximal development (ZPD)". When teachers carry out the teaching tasks, they should create better "zone of proximal development (ZPD)" continually, starting from the differences of the levels. Only in this way can the students' potential be developed, and can the students get more progress ( $\mathrm{Li}$, 2015).

American scholar Krashen also maintained that students should accept "understandable language input", which means the second language input a little more difficult than the current language lever, as much as they can when they are learning a language. Students can learn the new language truly when they put attention to the knowledge with unknown information but in familiar form. So we can see that graded teaching pattern has more solid theoretical basis already, 
and the basis can instruct the the graded teaching pattern to be applied into the actual teaching activities.

\section{The Application of the Graded Teaching Pattern in the College English Classroom Teaching}

\subsection{Graded Texts}

As a language discipline, English is more practical. Its teaching contents include five aspects as listening, speaking, reading, writing and translating. It is unreasonable for teachers to ask students to use identical texts when they are teaching the students English as a foreign language. So the graded texts is the basis of the graded teaching pattern. It is also the first step of "teach students in accordance of their aptitude". When grading the texts, teachers should choose the right texts according to students' English basis. For example, for students of agriculture, forestry, art, sports and primary school education related majors, teachers should choose texts which focus on the basic English knowledge, help them build solid English basis and master the basic English skills. When in teaching, teachers should cultivate the basic skills in English listening, speaking and writing intentionally, help students to practice their knowledge and acquire the language communicative ability (Wang, 2012). In other words, teachers should not only consider the teaching objectives, but also the students' learning levels, the teachers' characteristics and suitable learning methods for students when choosing the texts. When texts, teachers and students interact well, the texts can be the suitable and scientific texts. Only this kind of texts can help students get more progress.

\subsection{The Graded Students and Principles}

The graded students include two kinds, one is dominant hierarchical teaching and the other is recessive hierarchical teaching. The dominant hierarchical teaching is also called as "Stratification Teaching Among the Classes", which graded the students into different levels according to fixed rules. Students of the same levels can form a new group and study with each other as a unity. While the recessive hierarchical teaching is also called "stratified teaching in the classroom" which mainly targets at the students that are already graded. It will not use the same way to grade the students as the dominant hierarchical teaching does. The teachers will carry out the targeted teaching when they already mastered the students' situations within the class. This new method of grading the teaching objects can reduce the probability of students' negative emotions, and avoid that they are stick with the label of "negative". Teachers can combine two ways of grading when they carry out the teaching activities. First, teachers can grade the students into two levels according to their majors, such as students of agriculture, forestry, art, sports and primary school education related majors can be divided as one group and then grade students of this level. In this part, teachers can group the students according to their English scores in college entrance examination or placement test after entering college. Students with higher scores 
can be classified as group A while students with lower scores are classified as group B. Students of group A have better English basis and stronger learning enthusiasm, so teachers should instruct students of this group in time and motivate their enthusiasm. However, students of group B is the majority of the students and they have limited English basis and weaker self-study ability. Thus for students of group B, teachers should put lecturing and practices on the equal positions. To the students with very weak English basis and poor English grammar and vocabulary knowledge, teachers should try to arouse their enthusiasm of learning English. At the same time, because of their limited self-study ability, teachers should combine lecturing in the class with tutoring after class in time, and provide more help to them (Yang, 2012).

\subsection{The Graded Teaching Goals}

According to the relevant requirements of the ministry of education, the newly enrolled college students who failed to meet the demand of high school English curriculum standard can make the general requirement as their college study goals. The relatively higher learning standards is for students with better learning basis and self-study abilities who already achieved better English levels in high schools. College authorities should insist on the principles of sorted guidance and "teach students in accordance of their aptitude" when arrange the teaching tasks in order to meet students' different needs of learning, and can make necessary adjustments to English teaching goals according to students' actual situations. For example, after completing four semesters of study, students of group A should attain the "higher requirements" as described in the college students' English requirements by the ministry of education, while group B students should attain the "general requirements".

\subsection{Carry out the Flexible Curriculum}

Graded teaching needs corresponding curriculum, and the class hour needs to have some certain elasticity. This kind of curriculum can give adequate learning space to students. Students with a firm academic foundation and better study ability can acquire more knowledge in the limited time, while students with poor learning foundation and ability can make use of the class time to remedy their lack of knowledge. Only in this way can achieve the graded teaching in the real sense. College authorities should grade the students and adjust the teaching content in time according to the teaching goals. Students of group A need more study time in the early stage, and the teaching contents should include reading-writing course, audio-oral course and foreign teacher practice course. They will achieve the "general requirements" of the relevant curriculum after finishing two-semester courses' study. Students of group B will need more sufficient time to learn knowledge, they will spent half of the class time on reading and writing learning, and the other half time on listening and speaking learning. After finishing this part of learning, students of group B can achieve the "general requirements" of the relevant curriculum. 


\subsection{Dynamic Teaching Management Mode}

Teachers can take the "rolling method" to manage students of different grades when they are carrying out graded teaching pattern in the teaching process. At the end of each semester, classes of different grades should adjust the inner structure within the class according to students' daily learning score, state and will. Basically, students can continue to the next study step as soon as their scores can reach the qualified level. While students whose scores fail to reach the qualified level will decreased to a lower level class to reinforce their study. Besides, college authorities can try the "exemption of College English management" when they are planning the college English study. All of the students can attend the national college English test level 4 after finishing the first two semesters' learning. For the students who can pass the test, college can accept their applications of exemption of College English. In this way, students can make full use of their limited time and reduce the waste of study time.

One thing to note is that the basis of graded teaching pattern is to secure students of different basises can all achieve progress on academic performance and solid English foundation during college sutdies. The above mentioned "rolling method" and "exemption of College English management" can make it possible that students of different grades can exchange and circulate with each other. The goal of the management methods is to arouse students' study will to a higher level and prompt them to achieve a better study effect by their own efforts. But in the actual teaching process, we found that some students prefer to be in a lower level class. Because it is easier to get good scores in a lower level class. The reasons for this phenomenon is that the test paper of classes of group A students is more difficult than that of classes of group B students. And English performance has direct effect on students' awards recommendation. So related management departments in colleges should give some policy preference to students of group A in order to secure that all of the students can take part in the competition in a relatively fair form. It can not only arouse the Study enthusiasm of students of group A, but also can promote other students to study hard in aim of getting into group $\mathrm{A}$.

\section{Reflection on the Application of the Graded Teaching Pattern in College English Teaching}

In recent years, the practical experience of various colleges has proven that the graded teaching pattern is in line with the requirements of higher education. It can let students feel relaxed when studying English, and will make the class easier too. The enthusiasm of students of different basis can be aroused. So it is very beneficial for teachers to organize class teaching. Besides, graded teaching pattern can make full use of the colleges' multimedia devices, improve the richness and vitality of classroom teaching, which can also help to lay foundation for arousing students' enthusiasm (Zhang, 2015).

However, the application of the graded teaching pattern still encounter some difficulties in our country. Since the enrollment expansion of domestic colleges 
and universities, the number of college English teachers can not meet the needs of English teaching in many colleges and universities. In addition, as the recruiting English teachers reduces, and the mobility of teachers greatly increases, many teachers lack the correct understanding of graded teaching pattern, which can also affect the actual teaching activities. At the same time, the research capacity of teachers is also limited. While graded teaching pattern requires teachers to analyze students of different grades and choose suitable teaching ways and contents to students of different grades. In other words, the teachers group also needs to do further study, try to reach in-depth understanding of students' needs, and help them to solve problems caused during their study process. Teachers should also study with each other and find out the teaching strategies and methods by communicating with each other.

The English teaching in domestic colleges and universities faces too many students in the class which leads to the problem of management difficulty. In addition, due to the limited teaching materials, students in many colleges and universities have English class at the same time. In fact, students can not be evenly distributed due to their different basis and majors. So colleges and universities will have to consider the size of class when allocating classes. However, colleges and universities can not arrange classes based on students' real situations at the time of enrollment. So it is difficult to accurately distinguish between different grades. Besides, students of group A are always arranged to study at evening class or on weekends due to the limited study time and teaching material, which will cause discontent among them. So teachers will need to communicate with college or university authorities and find out a reasonable way. On the other hand, students of group B will have inferiority feeling. Since their basis is already poor, and the grade difference will let them lose interest in learning English. Teachers will meet with difficulties when they organize these students to study, because these students' intention to cooperate is low. So how to arouse these students' study interests and improve their study effects becomes a difficult task for teachers.

\section{Conclusion}

The application of graded teaching pattern in college English teaching involves many segments in the teaching process and it is not an easy task. The significance of its application in the actual teaching activities is that it can improve students' study effect, boost their enthusiasm for English learning, and enhance the quality of teaching. In this process, teachers should fully understand the students' study backgrounds and basis, explore their interests and choose the suitable teaching ways. Only this way can promote the development of college English teaching toward positive direction, achieve a better teaching result and finally improve the overall quality of the higher talents.

\section{References}

Dai, J. (2015) The Construction of College English Blended Learning Model under the 
Graded Teaching Pattern. Journal of Chongqing Institute of Technology (Social Science edition), 11, 8 .

Li, Y. Y. (2015) Study on College English Teaching Reform in Common Colleges and Universities. Journal of Hubei Institute of Technology, 9, 138.

Wang, Y. J. (2012) The Feasibility Analysis on Strategies of Class Management in Large-Class Lectures of College English Teaching. Journal of Shandong Province Agricultural Management Cadre Institute, 3, 128.

Yang, Y. H. (2012) The Differences of Classroom Inquiry of Different Levels in College English Graded Teaching Pattern. Foreign Language Teaching Theory and Practice, 3, 236.

Zhang, C. P. (2015) Empirical Research on Higher Vocational English Teaching under the Background of Multilevel Students-Take Suzhou Agricultural Vocational and Technical College as an Example. Wuxi Vocational and Technical College Journal, 6, 56.

Submit or recommend next manuscript to SCIRP and we will provide best service for you:

Accepting pre-submission inquiries through Email, Facebook, LinkedIn, Twitter, etc. A wide selection of journals (inclusive of 9 subjects, more than 200 journals)

Providing 24-hour high-quality service

User-friendly online submission system

Fair and swift peer-review system

Efficient typesetting and proofreading procedure

Display of the result of downloads and visits, as well as the number of cited articles Maximum dissemination of your research work

Submit your manuscript at: http://papersubmission.scirp.org/

Or contact ce@scirp.org 